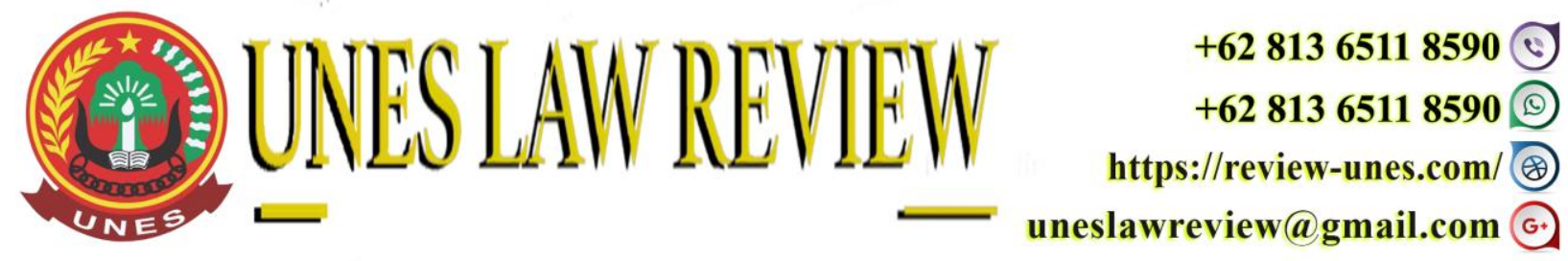

DOI: https://doi.org/10.31933/unesrev.v4i1

Diterima: 01/08/2021, Diperbaiki: 23/08/2021, Diterbitkan: 01/09/2021

\title{
PENERAPAN PRINSIP NON DISKRIMINASI KAITANNYA DENGAN KETENTUAN TINGKAT KANDUNGAN DALAM NEGERI DI INDONESIA
}

\author{
Violla Brazzy Upoyo", Emmanuel Ariananto Waluyo Adi ${ }^{2}$ \\ 1) Mahasiswi Program Magister Fakultas Hukum Universitas Indonesia, Jakarta, Indonesia \\ Email: violla.brazzy@gmail.com \\ 2) Analis Hukum Sekretariat Kabinet Republik Indonesia, Jakarta, Indonesia \\ Email: eadiwaluyo@gmail.com
}

Corresponding Author: Emmanuel Ariananto Waluyo Adi

\begin{abstract}
Countries that are members of the GATT General Agreement on Tariffs and Trade (GATT), including Indonesia, have agreed to apply the principle of non-discrimination in the activities of buying and selling goods between countries. Today's modern products are owned by everyone, namely mobile phones or computers. The product is an attraction to improve the economy of a country. Indonesia, which has ratified the GATT agreement contained in Law Number 7 of 1994 concerning Ratification of the Agreement Establishing the World Trade Organization also has regulations in Law Number 25 of 2017 concerning Investment which regulates the level of domestic content for business actors from abroad who will invest in the sector of selling mobile phone and computer products so that it contradicts the agreed principle of non-discrimination. This paper uses a normative approach with analytical techniques using hermeneutic analysis and interpretation methods. The author finds that there are no laws and regulations governing the exception to the principle of non-discrimination.
\end{abstract}

Keywords: Non-Discrimination, TKDN, Product

\begin{abstract}
ABSTRAK
Negara-negara yang tergabung dalam GATT General Agreement on Tarrif and Trade (GATT) termasuk Indonesia telah sepakat untuk menerapkan prinsip non diskriminasi dalam kegiatan jual beli produk barang antar negara. Produk modern saat ini dimiliki setiap orang yaiu handphone atau komputer. Produk tersebut menjadi daya tarik untuk meningkatkan ekonomi suatu negara. Indonesia yang telah meratifikasi kesepakatan GATT yang tertuang dalam Undang-Undang Nomor 7 tahun 1994 tentang Pengesahan Agreement Establishing the World Trade Organization juga memiliki regulasi dalam UU Nomor 25 Tahun 2017 tentang Penanaman Modal yang mengatur tingkat kandungan dalam negeri terhadap pelaku usaha dari luar negeri yang akan
\end{abstract}


menanamkan modal di sektor penjualan produk handphone dan komputer sehingga kontradiksi dengan prinsip non diskriminasi yang telah disepakati. Tulisan ini menggunakan pendekatan normatif dengan teknik analisis menggunakan analisis hermeneutik dan metode interpretasi. Penulis menemukan bahwa belum ada peraturan perundanng-undangan yang mengatur pengecualian atas prinsip non diskriminasi.

Kata Kunci: Non Diskriminasi, TKDN, Produk

\section{PENDAHULUAN}

Pertumbuhan ekonomi global di tahun 2020, minus 2\% (dua persen) - minus 1,6\% (satu koma enam persen), menjadi bukti bahwa keterpurukan ekonomi Indonesia mencapai titik terendah selama dua dekade terakhir. Realisasi pertumbuhan ekonomi Indonesia sendiri mencapai minus 5,32\% (lima koma tiga puluh dua persen) di kuartal II dan diperkirakan pertumbuhan ekonomi akan naik mencapai minus 2,9\% (dua koma sembilan persen) - minus $1 \%$ (satu persen) (Badan Koordinasi Penanaman Modal, 2021). Guna menaikan pertumbuhan ekonomi maka perlu meningkatkan pula pendapatan nasional atau Produk Domestik Bruto (PDB) yang salah satunya dapat dilakukan dengan kegiatan investasi. Investasi merupakan salah salah satu komponen dari beberapa tindakan-tindakan hukum lainnya yang memiliki peranan penting. Investasi adalah:

1. Penanaman uang atau modal dalam suatu perusahaan atau proyek untuk tujuan memperoleh keuntungan.

2. Aktivitas yang berkaitan dengan usaha penarikan sumber-sumber (dana) yang dipakai untuk mengadakan barang modal pada saat sekarang, dan dengan barang modal akan dihasilkan aliran produk baru di masa yang akan dating (Salim HS dan Budi Sutrisno, 2008:31). Investasi dikonstruksikan sebagai sebuah kegiatan untuk Penarikan sumber dana yang digunakan untuk pembelian barang modal; dan Barang modal itu akan dihasilkan produk baru.

Semakin tinggi tingkat investasi di suatu negara maka akan berdampak kepada pendapatan nasional sehingga terjadi peningkatan terhadap penggunaan barang dan jasa akan. Negara-negara yang berhimpun kemudian membentuk suatu persetujuan dagang dan tarif atau yang disebut General Agreement on Tariff and Trade (GATT). Indonesia sebagai salah satu pendiri WTO juga telah meratifikasi persetujuan pembentukan WTO melalui lahirnya Undang-Undang Nomor 7 tahun 1994 tentang Pengesahan Agreement Establishing the World Trade Organization (Persetujuan Pembentukan Organisasi Perdagangan Dunia) (“UU No. 7/1994”). Dengan lahirnya UU No. 7/1994, Indonesia meratifikasi GATT dan seluruh hal termasuk prinsip-prinsip yang ada di dalamnya yakni Trade Related Investment Measures (TRIMs) yang merupakan ketentuan investasi yang berkaitan dengan perdagangan dan merupakan bentuk upaya pemerintah dengan terus meningkatkan, memperluas, memantapkan dan mengamankan pasar bagi segala produk baik barang maupun jasa termasuk di dalamnya aspek investasi di Indonesia agar memiliki kemampuan daya saing terutama dalam perdagangan internasional. Indonesia menuangkan pengaturan Investasi dalam Undang-Undang Nomor 1 tahun 1967 tentang Penanaman Modal 
Asing dan Undang-Undang Nomor 6 Tahun 1968 tentang Penanaman Modal Dalam Negeri yang kemudian diubah kembali pada Undang-Undang Nomor 25 tahun 2007 tentang Penanaman Modal

Terdapat pengaturan investasi atas produk barang dan jasa yaitu kewajiban Tingkat Kandungan Dalam Negeri (TKDN) yang merupakan salah satu gagasan pemerintah Indonesia agar para pemilik brand atau vendor tidak hanya menjadikan Indonesia sebagai konsumen dan/atau pasar saja melainkan menjadikan para pemilik brand atau vendor memiliki niat untuk berinvestasi di Indonesia. Indonesia sebagai salah satu dari negara ke-4 (keempat) dengan jumlah penduduk terbesar di dunia, setelah China, India dan Amerika Serikat menjadikannya negara yang saat ini sadar akan pentingnya teknologi dan hal itu yang membuat pasar di Indonesia sangat berpotensial untuk penjualan telepon seluler/ponsel (Lucky Sebastian, 2021). Namun, jika hanya menjadi pasar terhadap telepon seluler/ponsel maka Indonesia hanya menjadi konsumen tetapi dengan aturan mengenai TKDN, pemerintah ingin mengubah kondisi pasar yang tadinya Indonesia hanya menjadi konsumen menjadikan para pemilik brand atau vendor menjadi tertarik untuk berinvestasi di Indonesia dengan ketentuan TKDN yang ada. Impor ponsel pada 2017 tercatat sebanyak 11,4 juta unit atau lebih rendah dari realisasi setahun sebelumnya yang sebesar 18,5 juta unit. Sementara itu, produksi ponsel nasional tembus 60 juta unit pada 2017. Keberlakuan TKDN di Indonesia tentunya menjadi polemik yang sampai saat ini menjadi perdebatan sebab di dalam Perjanjian TRIMs (perjanjian tentang aturan-aturan investasi yang menyangkut atau berkaitan dengan perdagangan) dimana Indonesia termasuk negara pihak, anggota WTO menerapkan prinsip non diskriminasi (national treatment) dan dilarang untuk menerapkan persyaratan kewajiban pemenuhan TKDN dalam aturan investasi dimana ketentuan TKDN terdapat dalam regulasi Indonesia. Tulisan ini bertujuan untuk menganalisis masalah tersebut.

\section{METODE PENELITIAN}

Tulisan ini menggunakan pendekatan normatif yang tidak hanya mengkaji hukum dalam arti peraturan perundang-undangan tetapi mencakup aspek yang lebih luas, yaitu sesuatu yang dapat ditelusuri melalui literatur. Teknik analisis yang digunakan dalam penelitian ini adalah metode analisis hermeneutik dan interpretasi. Analisis hermeneutik digunakan untuk memahami teks sebagai rangkaian tanda yang disusun sedemikian rupa oleh pengarang untuk menyampaikan makna tertentu. Sebaliknya, analisis interpretasi digunakan untuk menafsirkan dan mengungkapkan esensi ontologis, epistemologis, dan aksiologis yang terkait dengan tujuan penelitian ini.

\section{HASIL DAN PEMBAHASAN}

Dampak ratifikasi General Agreement on Tarrif and Trade (GATT) dan Trade Related Investment Measures (TRIMs) bagi Indonesia.

Dengan telah diratifikasinya Perjanjian World Trade Organization (WTO) oleh Indonesia dengan Undang-Undang Nomor 7 Tahun 1994 tanggal 2 November 1994 tentang pengesahan 
(ratifikasi) "Agreement Establising the World Trade Organization", maka Indonesia secara resmi telah menjadi anggota WTO dan semua persetujuan yang ada di dalamnya telah sah menjadi bagian dari legislasi nasional (E. Saefullah Wiradipradja, 2002:1). Indonesia adalah salah satu negara anggota GATT yang bergabung sejak tanggal 24 Februari 1950, dan kemudian menjadi original member WTO serta meratifikasi perjanjian perdagangan multilateral tersebut dengan Undang-Undang Nomor 7 Tahun 1994 Tentang Pengesahan Agreement Establishing the World Trade Organization (Persetujuan Pembentukan Organisasi Perdagangan Dunia) (Hata, 1998:241). Keterkaitan Indonesia menjadi anggota WTO ini juga berarti Indonesia memiliki dampak ikatan untuk ikut melaksanakan seluruh hasil keterikatan dalam melaksanakan seluruh hasil kesepakatan yang ada pada perundingan Uruguay salah satunya mengenai kebijakan dalam pembatasan investasi yang berkaitan dengan perdagangan atau Trade Related Investment Measures (TRIMs). Walaupun sejatinya peraturan mengenai penanaman modal asing tidak secara eksplisit termuat di dalam Perjanjian WTO baik dalam GATS maupun Agreement on TRIMs namun secara spesifik rumusan terkait prinsip-prinsip perdagangan bebas yang telah dinegosiasikan dalam putaran Uruguay tahun 1947, prinsip non diskriminasi yang terdiri atas Most Favoured Nation (MFN) dan National Treatment Principle (NT). Most Favoured Nation adalah pemberian perlakuan sama kepada negara yang satu dengan negara yang lain terhadap negara penerima penanaman modal sedangkan dalam National Treatment mengharuskan adanya perlakuan yang sama antara produk negara tuan rumah dengan produk serupa dari luar negeri (Muhammad Sood, 2012:25).

Kewajiban yang menjadi dasar adanya National Treatment Principle mengakibatkan diperlukannya perlakuan yang sama kepada warga negara asing dengan warga negara sendiri dimana berlaku bagi suatu barang atau produk yang diproduksi domestik atau dalam negeri dan terhadap barang produksi asing atau pun luar negeri. Apabila melihat kepada ketentuanketentuan TRIMs, sebenarnya memiliki dasar mengenai penekanan yang sama pada ketentuan National Treatment Principle dalam GATT yakni "treatment no less favourable" namun hanya berbeda pada pengendalian yang menyesuaikan pada masing-masing bidang. Walaupun TRIMs tidak secara gamblang menyertakan National Treatment Principle didalam isi ketentuannya namun diatur pada Pasal II TRIMs yang menyatakan bahwa segala bentuk tindakan yang dianggap tidak konsisten dengan National Treatment Principle merupakan hal yang tidak sesuai dengan Pasal III:4 GATT yang mana dalam Pasal tersebut menyatakan "treatment no less favourable" sangat diwajibkan dalam National Treatment Principle. Ketentuan pada TRIMs memberlakukan ketentuan di dalam GATT hanya dalam bidang investasi asing atau penanaman modal asing khususnya untuk bidang perdagangan barang seperti halnya yang ditegaskan di dalam Pasal 1 TRIMs (Munir Fuady, 2004:5) yang menyatakan "This Agreement applies to investment measures related to trade in goods only (referred to in this Agreement as "TRIMs". Pada bagian Annex Perjanjian TRIMs telah diletakkan pula illustrative list untuk memberikan kejelasan berkenaan dengan bentuk tindakan negara bagaimana yang dianggap tidak konsisten dengan National Treatment Principle menurut Pasal III:4 GATT (Dwi Martini, 2012). Berdasarkan illustrative list tersebut terdapat dua hal yang dianggap sebagai tindakan yang tidak 
konsisten dengan National Treatment Principle diantaranya adalah local content requirement dan trade balancing policy. Local content requirement terjadi dalam hal apabila negara dengan maksud demi memperoleh keuntungan kemudian membuat suatu kebijakan dengan memberlakukan hukum atau peraturan nasional berupa persyaratan yang mewajibkan pihak investor asing untuk membeli atau dengan menggunakan produk-produk domestic atau sumber apa pun yang sumbernya berasa dari dalam negeri apabila ia akan berinvestasi di dalam negeri.

Berbeda halnya dengan trade balancing policy menurut illustrative list terjadi dalam hal apabila pembelian dan/atau penggunaan produk impor oleh pihak investor asing yang berinvestasi di dalam negeri digantungkan pada jumlah atau nilai produk lokal yang diekspor. Dua unsur yang mengindikasikan bahwa kebijakan suatu negara nerupakan bentuk dari tindakan trade balancing policy diantaranya:

1. Penggunaan atau pembelian barang impor oleh pihak investor asing hanya dibenarkan apabila pihak investor asing bersangkutan tersebut telah mengimpor produk yang menggunakan importir dalam negeri;

2. Jumlah barang impor yang boleh digunakan oleh pihak investor asing dibatasi atau hanya sampai batas jumlah tertentu berdasarkan volume atau nilai produk lokal yang telah di ekspor oleh pihak investor asing bersangkutan tersebut

\section{Pengaturan Prinsip Non Diskriminasi Pada Peraturan Perundang-Undangan terkait Investasi di Indonesia}

Laju investasi di Indonesia tidak dapat dipungkiri berkembang dengan beberapa faktor diantaranya dipengaruhi adanya perkembangan globalisasi serta berkembangnya regulasi hukum yang mengatur mengenai investasi itu sendiri. Faktor penting dalam kegiatan investasi diantaranya adalah kemudahan mendirikan usaha, tidak ada diskriminasi bagi investor asing, perlakuan yang sama bagi investor asing dan lokal, transparansi dalam perizinan, kebijakan imigrasi, mekanisme penyampaian keluhan kepada pemerintah serta pemerintah yang responsif terhadap keluhan-keluhan yang diajukan (Teddy Reinier Sondakh, 2009:11). Hal tersebut memiliki korelasi dengan prinsip-prinsip transparansi yang merupakan salah satu prinsip yang termaktub dalam GCG (Good Corporate Governance) serta pada prinsip perlakuan yang sama (non diskriminasi) yang merupakan salah satu pilar utama legal basis World Trade Organization. World Trade Agreement membentuk suatu badan World Trade Organization yang merupakan suatu lembaga yang memiliki fungsi untuk melaksanakan berbagai perjanjian sebagaimana terkandung di dalam Final Act putaran Uruguay. Secara institusional, World Trade Organization sebagai pengganti dari General Agreement on Tarrif and Trade (GATT) yang hanya mengatur perdagangan barang, merupakan lembaga internasional dengan cakupan yang lebih luas dibandingkan dengan GATT. World Trade Organization sebagai organisasi pelaksana semua hasil Putaran Uruguay, selain menggarap isu-isu tradisional seperti penghapusan dan pengurangan tarif serta non-tarif, juga mencakup isu-isu baru seperti perlindungan Hak atas Kekayaan Intelektual (Trade Related Aspect of Intellectual Property Rights atau TRIPs), investasi yang dikaitkan dengan kebijaksanaan perdagangan (Trade Related Investment 
Measures atau TRIMs), dan perjanjian mengenai perdagangan jasa-jasa (General Agreement on Trade in Services atau GATS) (Hualo Adolf, 2002:15).

Semenjak Indonesia memberlakukan Undang-Undang Nomor 7 Tahun 1994 tanggal 2 November 1994 tentang pengesahan (ratifikasi) "Agreement Establising the World Trade Organization", maka lahirlah pengaturan mengenai prinsip non diskriminasi dalam hukum investasi di Indonesia yang dapat dilihat dari segi dampak keberlakuan ratifikasi GATT dan Trims serta pengaturannya langsung di dalam Undang-Undang Nomor 25 tahun 2007 tentang Penanaman Modal. Permasalahan yang akan dibahas dalam tulisan ini yaitu terkait penerapan prinsip Non-Diskriminatif dalam hukum investasi di Indonesia dalam kaitannya dengan Kewajiban Penggunaan Tingkat Kandungan Dalam Negeri pada Produk Telepon Seluler, Komputer Genggam dan Komputer Tablet di Indonesia. Awal mulanya pengaturan mengenai penanaman modal di Indonesia dibedakan atas pengaturan penanaman modal dalam negeri dan penanaman modal asing dalam regulasi yang berbeda. Pada Penanaman Modal Asing diatur pada Undang-Undang Nomor 25 tahun 2007 tentang Penanaman Modal (“UUPM"). Keberadaan UUPM merupakan cikal bakal pengaturan mengenai penanaman modal di Indonesia yang telah meniadakan ketentuan yang bersifat diskriminasi antara penanam modal asing dengan penanam modal dalam negeri. Indonesia merupakan salah satu negara yang telah meratifikasi persetujuan pembentukan World Trade Organization melalui lahirnya Undang-Undang Nomor 7 tahun 1994 tentang Pengesahan Agreement Establishing the World Trade Organization (Persetujuan Pembentukan Organisasi Perdagangan Dunia) (“UU No. 7/1994”). Dalam UU No. 7/1994, Indonesia meratifikasi GATT dan seluruh hal termasuk prinsip-prinsip yang ada di dalamnya yakni Trade Related Investment Measures (TRIMs) yang merupakan ketentuan investasi yang berkaitan dengan perdagangan dan sudah menjadi kewajiban dari Indonesia sendiri untuk sepatutnya melaksanakan prinsip-prinsip hukum yang telah disepakati dan tertuang di dalamnya. Salah satu prinsip yang wajib diterapkan di dalam regulasi nasional bagi negara-negara yang merupakan anggota World Trade Organization adalah prinsip non diskriminasi penanaman modal yang meliputi most favoured nation principle dan national treatment principle.

Asas yang melandasi kegiatan penanaman modal di Indonesia yakni asas perlakuan yang sama dan tidak membedakan asal negara. Pemerintah Indonesia memberikan perlakuan yang sama bagi penanam modal dalam negeri juga penanam modal asing lewat kebijakan dasar penanaman modal di Indonesia. Pemerintah memberikan perlakuan yang sama kepada semua penanam modal yang berasal dari negara manapun yang akan melakukan penanaman modal di Indonesia sesuai dengan ketentuan peraturan perundang-undangan yang berlaku, perlakuan tersebut tidak berlaku bagi penanam modal dari suatu negara yang memperoleh hak istimewa berdasarkan perjanjian dengan Indonesia. Perlakuan terhadap penanaman modal, pemerintah tidak akan melakukan tindakan nasionalisasi atau pengambilalihan hak kepemilikan penanaman modal kecuali dengan undang-undang. Indonesia telah mewujudkan prinsip non diskriminasi ke dalam UUPM dengan memberi banyak fasilitas bagi keberadaan penanam modal asing. Tetapi meskipun pemerintah memberikan fasilitas dan peluang yang sama kepada penanam modal asing sama dengan penanaman modal domestik tetapi tetap pemerintah memberikan perlindungan 
kepada pengusaha domestik seperti tertera dengan menetapkan peraturan mengenai bidangbisang usaha kecil menengah seta menerapkan pola kemitraan antara usaha kecil menengah dan usaha besar. Prinsip Non Diskriminatif yang diterapkan di Indonesia menjadikan Indonesia tidak dapat mempromosikan industri dalam negeri. Melalui ketentuan ini tidak ada batasan-batasan antar negara dalam lalu lintas perdagangan maupun laju investasi karena keseluruhan negara anggota yang telah bersatu menjadikan bebas dan terbukanya lalu lintas perdagangan dan laju investasi itu sendiri. Semakin dimudahkannya akses tersebut maka akan berdampak tajamnya persaingan industri perdagangan dan investasi. Realisasi National Treatment Principle dalam penanaman modal asing di Indonesia sesungguhnya tidak menutup semua kemungkinan yang ada bagi Indonesia dalam memajukan industry nasional karena sejatinya GATT tidak memberikan larangan proteksi terhadap industri nasional selama proteksi termaksud diberikan hanya melalui tarif.

\section{Tingkat Kandungan Dalam Negeri pada Produk Telepon Seluler, Komputer Genggam dan Komputer Tablet di Indonesia}

Indonesia turut memberlakukan local content requirements bagi penanaman modal asing. Penerapan Local Content atau lebih umum dikenal dengan TKDN pada dasarnya memiliki manfaat yang berguna bagi negara berkembang.Sebagai suatu kebijakan, tingkat kandungan dalam negeri mengisyaratkan bahwa bagi perusahaan multinasional dalam menggunakan prosentasi tertentu dari bahan dan komponen-komponen tertentu yang diproduksi dalam negeri sehingga dapat meningkatkan kegiatan industry domestiknya (Larry D. Qiu dan Zhigang Tao, 2011). Local content requirements merupakan suatu kebijakan yang dilarang karena tindakan tersebut merupakan bentuk perlakuan diksriminatif terhadap barang impor. Dengan adanya kewajiban bagi investor untuk membeli atau menggunakan barang-barang buatan dalam negeri, maka dalam hal ini Pemerintah telah memberikan perlakuan yang lebih baik pada barang buatan dalam negeri (Esty Hayu Dewanti, 2012:207). Melalui persyaratan kandungan lokal sebenarnya Pemerintah host country telah membatasi akses pasarnya bagi barang-barang yang sama dari negaranegara anggota lain. Di sisi lain, untuk memelihara kualitas produk akhir yang dihasilkan negara berkembang, perusahaan multinasional perlu untuk melakukan transfer teknologi terhadap industri domestik yang memproduksi komponen lokal. Oleh karena itu, local content requirements merupakan kebijakan populer Pemerintah negara berkembang yang berkaitan dengan penanaman modal asing. Di Indonesia kebijakan Local Content Requirements dituangkan dalam Program Peningkatan Penggunaan Produk Dalam Negeri (P3DN) dengan tujuan untuk memberdayakan produk nasional dengan prosentase kandungan lokal tertentu demi melindungi industri domestik dari serbuan produk impor (national protection).

Pengaturan mengenai local content atau tingkat kandungan dalam negeri sebenarnya tidak diatur secara terperinci di dalam UUPM namun pada kenyataannya Indonesia memberikan tindakan khusus bagi para investor ataupun perusahaan multinasional yang memakai produk dalam negeri melalui fasilitas-fasilitas yang telah disediakan oleh Pemerintah. Hal tersebut dapat dilihat pada Pasal 18 ayat (3) huruf f UUPM yang menyatakan bahwa "Penanaman modal yang 
mendapat fasilitas sebagaimana dimaksud pada ayat (2) adalah yang sekurang-kurangnya memenuhi salah satu kriteria berikut ini : $(f)$ industri yang menggunakan barang modal atau mesin atau peralatan yang diproduksi dalam negeri." Dalam pasal tersebut dapat diyakini bahwa pengaturan mengenai investasi di Indonesia secara implisit mengakui adanya usaha pemerintah dalam memberikan perlakuan yang lebih baik untuk barang buatan dalam negeri. Beberapa bentuk fasilitas yang dimaksud dalam ketentuan Pasal 18 ayat (3) UUPM dapat berupa pengurangan pajak penghasilan dari penghasilan netto sampai tingkat tertentu, pembebasan atau keringanan bea masuk atas impor barahan baku, barang modal, mesin atau impor peralatan untuk keperluan produksi yang belum dapat diproduksi dalam negeri, pembebasan atau penangguhan pajak pertambahan nilai atas impor barang modal atau mesin, serta keringanan pada pajak bumi dan bangunan.

Sebagai negara yang berkembang, Indonesia memerlukan upaya penerapan local content guna menjaga serta melindungi kepentingan nasional di dalam era kompetitif yang terbuka antar negara berkembang dalam laju investasi asing. Kebijakan TKDN atau local content penting guna mendorong perkembangan industri dan memantapkan Indonesia sebagai penyedia peralatan elektronik di Indonesia. Terdapat 3 (tiga) bentuk persyaratan yang dapat ditemukan dalam penerapan Local Content Requirements oleh negara penerima modal yang memuat aspek diantaranya sebagai berikut:

1. Pembelian atau penggunaan barang-barang buatan dalam negeri

2. Jumlah kandungan lokal yang dipergunakan dalam proses produksi ditentukan secara pasti

3. Merupakan syarat yang harus dipenuhi untuk dapat melakukan kegiatan investasi asing (Sanwani Nasution dan Mahmul Siregar, 2009:206).

Ketiga persyaratan tersebut menimbulkan beberapa polemic diantaranya adanya diskriminasi terhadap barang impor, pemaksaan terselubung untuk membeli produk dalam negeri, pemilik modal kehilangan kesempatan untuk menentukan pilihan kebijakan dalam menjalankan usahanya serta pelaku usaha domestic yang tidak kompetitif untuk jangka panjang.

Peraturan lainnya yang mengatur mengenai local content requirements juga ditemukan lebih khusus di dalam Peraturan Menteri Perindustrian Republik Indonesia Nomor 16/MInd/Per/2/2011 tentang Ketentuan dan Tata Cara Penghitungan Tingkat Komponen Dalam Negeri ("PERMEN INDUSTRI NOMOR 16/2011"), hal ini ditegaskan pula dalam Nota Kesepahaman Departemen Perindustrian Republik Indonesia dengan Kementerian Badan Usaha Milik Negara Nomor 522/M-Ind/12/2005 tentang Pengutamaan Penggunaan Produk Dalam Negeri. Adanya beberapa peraturan tersebut diatas membuktikan diakui adanya Tingkat Kandungan Dalam Negeri sebagai usaha pemerintah akan produk nasional di tengah berkembangnya produk impor yang mulai membanjiri pasaran di Indonesia dan juga digunakan sebagai dasar dalam rangka peningkatan penggunaan produk dalam negeri.

Lebih lanjut perkembangan sektor teknologi informasi dan komunikasi khususnya untuk perangkat telekomunikasi memiliki peningkatan yang begitu pesat. Melihat akan hal tersebut Pemerintah memberlakukan serta menetapkan kewajiban untuk produk telepon seluler memenuhi Tingkat Komponen Dalam Negeri. Tujuan dari diterapkannya regulasi TKDN ialah 
untuk memajukan produksi komponen lokal industri telepon seluler dalam negeri, serta menjadikan pertumbuhan dan perkembangan sektor TIK menjadi lebih berkualitas dan berkontribusi besar terhadap kepentingan nasional, khususnya peningkatan pada penggunaan konten lokal, baik hardware atau perangkat keras maupun software atau perangkat lunak.

Pemerintah Nomor 29 Tahun 2018 Tentang Pemberdayaan Industri ("PP NOMOR 29/2018”) pada Pasal 56 menjelaskan Lingkup pengaturan peningkatan penggunaan Produk Dalam Negeri meliputi salah satunya TKDN.Produk Dalam Negeri wajib digunakan oleh pengguna Produk Dalam Negeri sebagai berikut:

1. lembaga negara, kementerian, lembaga pemerintah non kementerian, lembaga pemerintah lainnya, dan satuan kerja perangkat daerah dalam pengadaan Barang/Jasa apabila sumber pembiayaannya berasal dari anggaran pendapatan dan belanja negara, anggaran pendapatan dan belanja daerah, termasuk pinjaman atau hibah dari dalam negeri atau luar negeri; dan

2. badan usaha milik negara, badan hukum lainnya yang dimiliki negara, badan usaha milik daerah, dan badan usaha swasta dalam pengadaan Barang/Jasa yang:

a. pembiayaannya berasal dari anggaran pendapatan dan belanja negara atau anggaran pendapatan dan belanja daerah;

b. pekerjaannya dilakukan melalui pola kerja sama antara Pemerintah Pusat dan/atau Pemerintah Daerah dengan badan usaha; dan/atau

c. mengusahakan sumber daya yang dikuasai negara

Peraturan Menteri Komunikasi dan Informatika Nomor 27 Tahun 2015 tentang Persyaratan Teknis Alat dan/atau Perangkat Perangkat Telekomunikasi Berbasis Standar Teknologi Long Term Evolution ("PERMENKOMINFO NOMOR 27/2015") pada Pasal 4 ayat (1) menyebutkan mengenai ketentuan, bahwa perangkat Telekomunikasi berbasis standar teknologi Long Term Evolution (LTE) yang dibuat, dirakit, dimasukkan untuk diperdagangkan dan/atau digunakan di Wilayah Negara Indonesia memiliki kewajiban untuk memenuhi Tingkat Komponen Dalam Negeri (TKDN) paling rendah 30\% untuk produk Base Station dan paling rendah 20\% untuk produk Subscriber Station. Sejak tanggal 1 Januari 2017 TKDN untuk telekomunikasi berbasis standar teknologi LTE yang beroperasi pada pita frekuensi radio $2100 \mathrm{MHz}, 900 \mathrm{MHz}, 800$ $\mathrm{MHz}$.

Kemudian pada Peraturan Menteri Perindustrian Nomor 29/M-IND/PER/7/2017 tentang Ketentuan dan Tata Cara Penghitungan Nilai Tingkat Komponen Dalam Negeri Produk Telepon Seluler, Komputer Genggam, dan Komputer Tablet ("PERMEN INDUSTRI NOMOR 29/2017'). Definisi Tingkat Komponan Dalam Negeri sesuai PERMEN INDUSTRI NOMOR 29/2017 adalah besarnya komponen dalam negeri,pada produk telepon seluler, komputer genggam atau komputer tablet yang mana tujuannya diterapkannya regulasi tersebut adalah guna memajukan produksi komponen lokal industry telepon seluler dalam negeri serta menjadikan perkembangan sektor teknologi informasi dan komunikasi menjadi lebih berkualitas namun tetap memperhatikan kepentingan nasional. Perhitungan nilai Tingkat Kandungan Dalam Negeri dengan tiga skema, yakni skema perhitungan hardware, skema perhitungan software, dan skema perhitungan berbasis pengembangan inovasi. Lingkup pengaturan PERMEN INDUSTRI 
NOMOR 29/2017 ini meliputi ketentuan penghitungan nilai Tingkat Kandungan Dalam Negeri, tata cara penghitungan nilai Tingkat Kandungan Dalam Negeri, lembaga verifikasi dan pengawasan. Selain memberikan dampak yang signifikan bagi Indonesia sendiri dalam memberlakukan kewajiban penggunaan tingkat kandungan dalam negeri hal ini dirasa juga menarik para investor asing dalam melakukan investasi di Indonesia. Investasi di sector ini meningkat karena adanya investasi perluasan pada produk telepon genggam, yang salah satunya menerapkan surface mount technology pada proses manufaktur ponsel di beberapa pabrik dalam negeri. Pasal 4 PERMEN INDUSTRI NOMOR 29/2017 menyebutkan bobot:

1. Aspek manufaktur dengan bobot $70 \%$ (tujuh puluh persen) dari penilaian TKDN produk

2. Aspek pengembangan dengan bobot $20 \%$ (dua puluh persen) dari penilaian TKDN produk

3. Aspek aplikasi dengan bobot $10 \%$ (sepuluh persen) dari penilaian TKDN produk.

Keberlakuan aturan mengenai TKDN tersebut berlaku maka produk yang tidak memenuhinya tidak akan diperbolehkan dijual di Indonesia. Vendor harus memakai komponen, produk atau jasa dari dalam negeri dalam hal ini Indonesia untuk merakit produknya dan memperoleh nilai TKDN yang dipersyaratkan sehingga dapat tetap berjualan atau berproduksi di Indonesia. produk dalam negeri adalah barang/jasa termasuk rancang bangun dan perekayasaan yang diproduksi atau dikerjakan oleh perusahaan yang berinvestasi dan berproduksi di Indonesia, yang dalam proses produksi atau pengerjaannya dimungkinkan penggunaan bahan baku/komponen impor. Dengan lain perkataan bagi para investor atau vendor yang ingin berinvestasi di Indonesia khususnya pada produk telepon seluler, komputer genggam dan komputer tablet, harus memerhatikan adanya ketentuan mengenai TKDN yang mengatur mengenai produk terkait.

Dari diterapkannya regulasi mengenai Tingkat Kandungan Dalam Negeri terhadap industry pada sektor Teknologi Informasi dan Komunikasi di Indonesia didapati beberapa hasil diantaranya sebagai berikut:

1. Jumlah penjualan telepon seluler 4G LTE

2. Kapasitas produksi telepon seluler 4G LTE

3. Penggunaan material produksi dalam negeri

4. Proses pengembangan atay R\&D oleh engineer WNI

5. Jumlah aktif user dari pengguna aplikasi buatan dalam negeri

6. Jumlah tenaga kerja WNI dalam proses produksi di dalam negeri

7. Jumlah engineer WNI dalam proses pengembangan atau R\&D di dalam negeri

8. Jumlah engineer WNI dalam proses pembuatan aplikasi di dalam negeri

9. Penanaman investasi untuk menunjang proses produksi di dalam negeri

10. Penanaman investasi untuk menunjang proses pengembangan di dalam negeri

11. Penanaman investasi untuk menunjang proses pembuatan aplikasi di dalam negeri (Airin Devanty, Muhammad Zilal Hamzah, Eleonora Sofilda, 2018).

Pada praktiknya TKDN bahwa para investor atau vendor tidak menjadikan regulasi sebagai halangan dalam berinvestasi di Indonesia khususnya pada sektor teknologi informasi dan komunikasi. Namun dalam penerapannya masih ditemukan beberapa kendala dalam memenuhi 
perysratan mengenai TKDN diantaranya alur perizinan yang masih berjalan dengan tidak efisien, kualitas dalam negeri yang masih belum memenuhi syarat kualitas tertentu juga biaya dan waktu produksi yang tergolong masih tinggi sedangkan kendala yang dirasa merek lokal yakni persaingan ketat yang semakin dirasa dengan produk merek asing.

\section{Prinsip Non Diskriminasi terhadap Kewajiban Penggunaan Tingkat Kandungan Dalam Negeri pada Produk Telepon Seluler, Komputer Genggam dan Komputer Tablet di Indonesia}

Berlakunya peraturan mengenai Local Content Requirements atau Tingkat Kandungan Dalam Negeri pada Produk Telepon Seluler, Komputer Genggam, dan Komputer Tablet berdampak pada permasalahan pokok dimana penerapannya sebagai salah satu upaya national protection akan bertolak belakang dengan prinsip non diskriminasi sebagaimana termaktub pada UUPM. Indonesia menerapkan bentuk penggunaan Tingkat Kandungan Dalam Negeri dalam pembelian atau penggunaan barang-barang buatan dalam negeri seperti elektronik maupun otomotif. Namun pada kenyataannya hampir beberapa perjanjian Internasional yang mengatur mengenai investasi atau perjanjian perdagangan bebas mengatur pula mengenai country specific exception. Pengecualian tersebut ditujukan untuk implementasi prinsip dari pada Most Favoured Nation (MFN) dan National Treatment yang diperlukan guna mendukung tujuan daripada investasi itu sendiri. Selain itu alasan yang mendasari yakni kondisi suatu negara yang memerlukan perlakuan khusus berkaitan dengan kondisi ekonominya dalam menghadapi pesatnya persaingan global.

Pelanggaran National Treatment Principle terjadi ketika performance requirements hanya diterapkan kepada investor asing, yang mana kutipannya sebagai berikut: "national treatment will certainty be violated if performance requirements are imposed only on foreign investors". menurutnya implementasi dari Tingkat Kandungan Dalam Negeri merupakan bentuk performance requirements yang dilarang dalam GATT apabila penerapannya kepada investor asing hanya bertujuan demi mendapatkan keuntungan yang sebesar-besarnya bagi negara penerima modal dan tidak dibebankan kepada industri domestiknya dan hal tersebut telah melanggar National Treatment Principle serta secara tidak langsung tidak menerapkan prinsip non diskriminasi bagi para investor asing. Pada dasarnya Indonesia memiliki beberapa pilihan untuk menerapkan pengecualian bidang-bidang yang akan dikenai Local Content dalam laju investasinya asal penerapannya dilakukan secara transparan dalam peraturan mengenai investasi itu sendiri yakni UUPM. Pilihan untuk menerapkan pengecualian dan secara transparan tersebut sebenarnya juga telah diatur oleh WTO karena WTO memberikan kebebasan negara dalam membatasi mengenai National Treatment Principle dengan catatan hal tersebut akan tertuang secara terbuka dan transparan dalam suatu peraturan atau undang-undang.

Pengenaan Tingkat Kandungan Dalam Negeri atau Local Content Requirement tidak termasuk dalam pengecualian National Treatment Principle di dalam UUPM. Dengan tidak adanya pengecualian tersebut akan berdampak Indonesia telah melanggar National Treatment Principle yang diatur pada GATT 1994 dimana Local Content dianggap sebagai suatu 
performance requirements yang akan menghambat perdagangan termasuk perdagangan dalam lingkup investasi pada bidang regulasi. Perjanjian Internasional tentang investasi maupun perjanjian perdagangan bebas telah mengatur tentang country specific exception yang ditujukan untuk penerapan dari pada prinsip Most Favoured Nation (MFN) atau National Treatment yang diperuntukan bagi tujuan investasi itu sendiri serta alasan lainnya salah satunya yakni sesuai kebutuhan kondisi ekonomi negara di dalam menghadapi persaingan global yang semakin memudahkan para investor untuk melakukan investasi dengan menghapus beberapa hambatanhambatan untuk berinvestasi. Beberapa hal yang mendasari pengecualian tersebut diantaranya sebagai berikut:

1. Negara sebagai pihak di dalam perjanjian memiliki hak untuk memberikan perlakuan berbeda antara investor asing dan investor domestik

2. Adanya perlakuan yang berbeda tersebut dituangkan dalam hukum dan peraturan-peraturan terkait di negara tersebut.

3. Alasan pemberlakuan country specific exception khususnya terhadap industri-industri atau aktivitas-aktivitas tertentu dan spesifik adalah karena kondisi perekonomian nasional dan kebijakan social,

Sebagai negara berkembang yang tengah memajukan laju investasi dengan memberi kemudahan bagi para investor-investor asing, pengecualian tersebut dapat dijadikan masukan bagi peraturan perundang-undangannya khususnya UUPM. Hak Pemerintah dalam memberi perlakuan yang berbeda antara investor asing sebagai wujud pengecualian dari prinsip non diskriminasi atau National Treatment Principle.

Pasal 3 TRIMs menyebutkan "All exceptions under GATT 1994 shall apply, as appropriate, to the provisions of this Agreement." sehingga dapat disimpulkan pemerintah memiliki hak untuk memberikan perlakuan yang berbeda terhadap investor asing sebagai bentuk dari pada pengecualian National Treatment Principle. Selain itu, upaya pemerintah dalam melindungi perekonomian negaranya ditengah maraknya serbuan produk-produk asing dapat menjadi alasan bagi Indonesia dalam memberlakukan penerapan TKDN sebagai suatu alternaltif yang dapat dilakukan guna melindungi industrinya dan produk domestik sehingga hal ini telah memenuhi unsur ketiga mengenai hal yang mendasari pengecualian sebagaimana telah disebutkan diatas. Namun pada UUPM hanya terbatas mengatur mengenai pengecualian prinsip non diskriminasi dengan membedakan bidang-bidang usaha yang tertutup dan terbuka atau bidang usaha yang terbuka dengan persyaratan. Penambahan aturan mengenai bidang-bidang usaha apa saja yang memiliki kewajiban untuk menerapkan TKDN sangat penting guna menghindari pandangan terjadinya inkonsistensi bagi Indonesia sebagai negara yang telah meratifikasi TRIMs dan GATT.

Mengacu kepada situasi pada saat ini diera pandemi Covid-19 beberapa upaya pemerintah khususnya pada sektor perekonomian menitikberatkan salah satunya pada laju investasi di Indonesia. Kementerian Perindustrian terus memacu agar industri di Indonesia khususnya pada bidang elektronika mengoptimalkan TKDN di setiap produk yang dihasilkannya. Lewat hal tersebut diharapkan dapat menarik investasi melalui penumbuhan 
sektor industri pendukung maupun komponen sehingga akan berdampak pula kepada berkembangnya perekonomian nasional. Selain itu, beberapa rencana pemerintah terkait revisi atas peraturan terkait ketentuan tata cara perhitungan nilai tingkat kandungan dalam negeri pada produk elektronika bertujuan salah satunya untuk menarik investasi melalui penumbuhan sektor industri pendukung atau komponen dengan memudahkan para investor asing yang memiliki niat berinvestasi di Indonesia namun dengan tidak melupakan aturan mengenai peran TKDN yang berguna bagi perkembangan perindustrian di Indonesia sendiri.

\section{PENUTUP}

Guna menaikan pertumbuhan ekonomi maka perlu meningkatkan pula pendapatan nasional atau Produk Domestik Bruto (PDB) yang salah satunya dapat dilakukan dengan kegiatan investasi. Tidak dapat dipungkiri bahwa semakin tinggi tingkat investasi di suatu negara maka akan berdampak kepada pendapatan nasional yang akan memiliki peningkatan dikarenakan peningkatan terhadap barang dan jasa akan bertambah. Perekonomian Indonesia saat ini juga tergantung pada percepatan Investasi. Keterkaitan Indonesia menjadi anggota WTO mengakibatkan Indonesia memiliki dampak ikatan untuk ikut melaksanakan seluruh hasil keterikatan dalam melaksanakan kebijakan dalam pembatasan investasi yang berkaitan dengan perdagangan atau Trade Related Investment Measures (TRIMs). Kewajiban yang menjadi dasar adanya National Treatment Principle mengakibatkan diperlukannya perlakuan yang sama kepada warga negara asing dengan warga negara sendiri dimana berlaku bagi suatu barang atau produk yang diproduksi domestik atau dalam negeri dan terhadap barang produksi asing atau pun luar negeri. Keberadaan UUPM merupakan cikal bakal pengaturan mengenai penanaman modal di Indonesia yang telah meniadakan ketentuan yang bersifat diskriminasi antara penanam modal asing dengan penanam modal dalam negeri. Untuk mendukung kelancaran kegiatan dalam investasi khususnya pada sektor teknologi informasi dan komunikasi maka seperti telepon seluler, komputer tablet dan komputer genggam sangat diperlukan untuk koordinasi pelaksanaanya. Pada praktiknya aturan pelaksanaannya telah tertuang didalam kebijakankebijakan Tingkat Kandungan Dalam Negeri yang dalam hal ini untuk produk telepon seluler, komputer tablet dan komputer genggam. Berlakunya peraturan mengenai Local Content Requirements atau Tingkat Kandungan Dalam Negeri pada Produk Telepon Seluler, Komputer Genggam, dan Komputer Tablet berdampak pada permasalahan pokok dimana penerapannya sebagai salah satu upaya national protection akan bertolak belakang dengan prinsip non diskriminasi sebagaimana termaktub pada UUPM. Pada Pasal 7 UUPM perlakuan terhadap penanaman modal, pemerintah tidak akan melakukan tindakan nasionalisasi atau pengambilalihan hak kepemilikan penanaman modal kecuali dengan undang-undang. Tetapi dalam kenyataannya, penulis menemukan inkonsistensi terhadap ketentuan pasal 7 UUPM yang menyatakan tidak akan ada diskriminasi seperti pemaksaan nasionalisasi tetapi kenyataan yang ada dalam PP NOMOR 29/2018 dan PERMENKOMINFO NOMOR 27/2015 masih mengatur nasionalisasi dengan memberlakukan komponen Tingkat Kandungan Dalam Negeri pada produk telepon seluler, komputer genggam dan komputer tablet. Hal tersebut dikhawatirkan akan 
berpengaruh dengan terganggunya pelaksanaan kegiatan investasi saat ini. Indonesia melalui berlakunya UUPM sudah selayaknya memperlakukan hal yang sama bagi penanam modal dalam negeri dan juga penanam modal asing. Asas yang melandasi kegiatan penanaman modal di Indonesia yakni asas perlakuan yang sama dan tidak membedakan asal negara maka sudah sepatutnya Indonesia juga memberikan jaminan hukum dengan memberikan perlakuan yang sama bagi para investor atau penanam modal asing. Pengecualian nasionalisasi hanya bisa melalui undang-undang dan saat ini belum ada undang-undang yang mengatur terkait TKDN. Selain itu sampai saat ini pun Program Legislasi Nasional Tahun 2021-2024 tidak ditemukan draft undang-undang terkait Tingkat Kandungan Dalam Negeri sebagai salah satu pedoman dasar yang berkaitan dengan laju investasi di Indonesia. Melihat akan hal tersebut maka penulis merekomendasikan bagi DPR dan Pemerintah untuk segera mempertimbangkan disusunnya Rancangan Undang-Undang Tingkat Kandungan Dalam Negeri pada Program Legislasi Nasional selanjutnya agar pelaksanaan kegiatan investasi berjalan lebih maksimal sehingga akan berdampak pula bagi pertumbuhan ekonomi di Indonesia yang akan meningkat.

\section{DAFTAR PUSTAKA}

Hata (1998), Aspek-aspek Hukum dan Non Hukum Perdagangan Internasional dalam Sistem GATT \& WTO, STHB Press, Bandung

HS. Salim dan Sutrisno. Budi (2004), Hukum Investasi di Indonesia, (Jakarta: RajaGrafindo Persada, 2008)

Munir Fuady, Hukum Dagang Internasional (Aspek Hukum dari WTO), Penerbit PT Citra Aditya Bakti, Bandung

Nasution, Sanwani dan Siregar, Mahmul, (2009) Perdagangan Internasional dan Investasi, Program Studi Ilmu Hukum, USU, Medan,

Sood, Muhammad (2012) Hukum Perdagangan Internasional, Jakarta: PT Raja. Grafindo Persada

Teddy Reinier Sondakh (2009), Implementasi Prinsip Transparansi Dalam Praktek Penanaman Modal di Indonesia, Bayumedia Publishing, Malang,

Dwi Martini, Prinsip National Treatment dalam Penanaman Modal Asing di Indonesia (Antara Liberalisasi dan Kepentingan Nasional), Jurnal Fakultas Hukum Universitas Mataram 5 Desember 2012

E. Saefullah Wiradipradja, Konsekuensi Yuridis Keanggotaan Indonesia dalam WTO- GATS dan Pengaruhnya terhadap Industri dan Perdagangan Jasa, Jurnal Hukum Internasional UNPAD Vol. I/I/2002, Bandung,

Esty Hayu Dewanti, Persyaratan Kandungan Lokal (Local Content Requirements) Di Indonesia Dan Kaitannya Dengan Perjanjian Internasional Di Bidang Investasi, Jurnal Yuridika: Volume 27 No 3, September-Desember 2012

Hualo Adolf, Pengaturan Perdagangan Jasa Khususnya Sektor Pariwisata dalam World Trade Organization, Jurnal Hukum Internasional Unpad Vo.1/1/2002 
Saefullah Wiradipradja, Konsekuensi Yuridis Keanggotaan Indonesia dalam WTO- GATS dan Pengaruhnya terhadap Industri dan Perdagangan Jasa, Jurnal Hukum Internasional UNPAD Vol. I/I/2002

Airin Devanty, Muhammad Zilal Hamzah, Eleonora Sofilda, "Analisis Dampak Regulasi Tingkat Komponen Dalam Negeri (TKDN) Terhadap Industri pada Sektor Teknologi Informasi dan Komunikasi di Indonesia”, Seminar Nasional Cendekiawan ke 4 Tahun 2018 ,

Larry D. Qiu dan Zhigang Tao, "Export, Foreign Direct Investment, and Local Content Requirement", ditulis untuk Seminar University of Hong Kong, Hong Kong University of Science and Technology, dan University of Tokyo, Maret, 2011

Undang-Undang Nomor 7 tahun 1994 tentang Pengesahan Agreement Establishing the World Trade Organization

Undang- Undang No. 25 Tahun 2007 tentang Penanaman Modal

Peraturan Menteri Perindustrian Republik Indonesia Nomor 16/M-Ind/Per/2/2011 tentang Ketentuan dan Tata Cara Penghitungan Tingkat Komponen Dalam Negeri

Peraturan Pemerintah Nomor 29 Tahun 2018 Tentang Pemberdayaan Industri

Peraturan Menteri Komunikasi dan Informatika Nomor 27 Tahun 2015 tentang Persyaratan Teknis Alat dan/atau Perangkat Perangkat Telekomunikasi Berbasis Standar Teknologi Long Term Evolution

Peraturan Menteri Perindustrian Nomor 29/M-IND/PER/7/2017 tentang Ketentuan dan Tata Cara Penghitungan Nilai Tingkat Komponen Dalam Negeri Produk Telepon Seluler, Komputer Genggam, dan Komputer Tablet

https:// bappenas.go.id

https:// bkpm.go.id

https://inet.detik.com

https://kbbi.web.id 